Cláudia Cristina Studart Leal' (https://orcid. org/0000-0003-1416-6127

Alexandre Martins Valença' Ohttps://orcid.org/0000-0002-5744-2112

\section{Alleged amnesia in sexual crime}

\author{
Alegação de amnésia em crime sexual
}

DOI: $10.1590 / 0047-2085000000281$

\section{ABSTRACT}

The current article describes the case of a man who claimed amnesia in relation to a sexual crime he had allegedly committed. Psychiatric examination concluded that the individual was feigning amnesia. Claimed amnesia of a criminal offense is one of the most commonly feigned symptoms in the forensic medical setting. It is thus necessary to rule out organic or psychogenic causes of amnesia and always consider feigned amnesia in the presence of psychopathological alterations that do not reflect classically known syndromes.

\section{KEYWORDS}

Crime, amnesia, simulation, criminal liability.

\section{RESUMO}

O presente artigo descreve o caso de um homem que alegou amnésia ao fato da denúncia de crime sexual que the foi imputada. A perícia psiquiátrica concluiu tratar-se de simulação. A alegação de amnésia da ofensa criminosa é um dos sintomas mais comumente simulados no ambiente pericial. Portanto, devem-se excluir as causas de amnésia orgânica ou psicogênica e sempre considerar a amnésia simulada na presença de alterações psicopatológicas que não configuram quadros sindrômicos classicamente conhecidos.

\section{PALAVRAS-CHAVE}

Crime, amnésia, simulação, responsabilidade penal. 


\section{INTRODUCTION}

Amnesia is characterized by a memory deficit, which can be transient or permanent. Wortzel and Arciniegas ${ }^{1}$ describe the impairment that can occur in encoding memory, related to new learning acquisitions or recall, that is, recalling previously learned situations, including anterograde or retrograde memories.

During criminal interviews in forensic psychiatry, it is common for the interviewee to claim amnesia in relation to the facts of the criminal complaint. According to Grondal et al. ${ }^{2}$, an average of $33 \%$ of criminal offenders claim amnesia in relation to the acts related to the crime. The prevalence is higher in more violent crimes such as homicides. Most criminals that claim amnesia of their offense are significantly older than those who do not claim amnesia ${ }^{3,4}$.

Taylor and Kopelman ${ }^{5}$ assessed 203 men who were under arrest and had committed non-violent and violent crimes (homicide, arson, and assault). None of those accused of nonviolent crimes reported amnesia of the act in question. Of the 34 convicted murderers, 26\% claimed amnesia (compared to $8 \%$ of the 120 criminals who had practiced other violent acts). A study by Pyszora et al. ${ }^{4}$ assessed 207 convicts serving life sentences in England and Wales in 1994 and found that $29 \%$ claimed amnesia of their criminal offense (among those committed of homicide, the figure was 31.4\%).

Cima et al. ${ }^{3}$ assessed a sample of 308 forensic psychiatric inpatients (180 in Germany and 128 in the Netherlands). Of these, 72 (23\%) claimed amnesia of their crimes; of these, 24 (33\%) had committed homicide, 18 (25\%) sexual crimes, 8 (11\%) serious physical assault, and 22 (31\%) arson and/or robbery.

A Canadian study ${ }^{6}$ of sex offenders at the Sexual Behaviors Clinic of the Royal Ottawa College found that those who claimed amnesia for their offenses had committed more violent acts and met the diagnostic criteria for potentially harmful paraphilias.

Jelicic ${ }^{7}$ describes three causes for alleged amnesia during crime: organic, psychogenic, or simulation. The origin of organic amnesia is a disease or injury, such as epilepsy, schizophrenia, head trauma, stroke, bipolar disorder, or alcohol or drug intoxication, among others. Psychogenic amnesia is a dissociative amnesia, caused by the incapacity to recall personal situations or events after a traumatic or stressful experience with a psychological origin'. Feigned amnesia is the intentional production or exaggeration of memory impairment with the motive of obtaining secondary gain, which in the case of crimes is to avoid the possibility of being penalized for the criminal act.

No studies were found in the Brazilian literature that cited the incidence of alleged amnesia among offenders. This may be due to the difficulty in selecting such samples.

Valença et al. ${ }^{8}$ conducted a study with a sample of 44 sex offenders in Rio de Janeiro, all of whom were men. No case of feigned amnesia was identified in the sample. Nineteen offenders (43.2\%) did not have a psychiatric diagnosis, nine (20.4\%) were diagnosed with mental retardation, and 16 (36.4\%) had a diagnosis of mental or neurological disorder.

In another study, Valença et al. ${ }^{9}$ conducted a literature review of sexual crimes and mental disorders. The most frequently diagnosed mental disorders were schizophrenia, bipolar disorder, and mental retardation. There were no reports of simulation.

The aim of this article, based on the case report technique, is to describe an individual accused of a sexual offense and who, doing the criminal proceedings, attempted to feign symptoms of amnesia. Publication of this case was authorized by the administration of the Heitor Carrilho Forensic Institute, where the forensic examination was performed.

\section{Evaluation in psychiatric expertise}

A white Brazilian male, 70 years old, married, retired, appeared at the Forensic Psychiatric Institute in Rio de Janeiro, Brazil, for a forensic examination involving criminal liability. According to the report by the Office of the Public Prosecutor, the individual had engaged in libidinous acts with a 15-year-old girl, other than sexual intercourse, namely fondling her buttocks, in exchange for the gift of a cellphone. He was thus on trial under Article 218-B, Heading, Section 2, Item I of the Brazilian Criminal Code, included under Law 12.015 of $2009^{10}$.

The accused claimed to the examiners, "I don't remember any girl at all. I don't remember her having asked for anything." In his clinical history, there was no report of delay in psychomotor development. He had started working as a child, on the farm with his siblings. He had been married for 40 years with his current wife, with three children. He had worked at different jobs, as a farmworker, butcher, car washer, green grocer, and finally as a truck driver, before retiring 10 years before the facts in question. On a voluntary basis, he had been president of his neighborhood association, remaining at this post until a year after the facts leading to his indictment.

The individual reported that he experienced episodes of psychomotor agitation with irritability and aggressiveness (not directed against others). He added that he is usually "disoriented" during such episodes, which tend to occur spontaneously, but that they are also precipitated by situations of greater affective stress. When asked to describe such alterations with greater detail, he was imprecise in his description and claimed to be unable to furnish such details.

At the very beginning of the interview, the wife of the accused states spontaneously to the examiner that she "believes in his innocence". She states that he spends most of his time at home engaging in personal activities (e.g., watching television). She says that his outbreaks occur for no apparent reason and last about 30 to 40 minutes. She 
adds that he cannot be in charge of certain household chores, that "he has already forgotten a pot on the stove". He is currently in psychiatric follow-up and medicated with sertraline and alprazolam. He reports no previous psychiatric hospitalizations, suicide attempts, or clinical alterations, and no history of accidents, injuries, surgery, alcohol or drug use, blood transfusion, or seizures.

The interviewee is evasive in his replies during most of the interview. He provides partially correct personal data, using approximate answers on some items in his personal identification. For example, when asked to state his age, he says 72 , but he gives his correct birthdate and is able to perform simple arithmetic correctly.

He gives the interviewer contradictory answers at more than one point in the interview. He claims that he cannot state his current or prior medical treatment, but as the interview proceeds, he answers affirmatively when asked about his use of psychoactive medication. When asked to memorize three words pronounced by the interviewer (after repeating them, namely "ball", "horse", and "brick"), he is initially unable to recall them when asked (after a short time), but he later says that one of the words is "cat".

The accused says he is unable to different between a dwarf and a child. Asked about the difference between a bird and an airplane, he says, "Both of them fly." Asked to do the figure "10 minus 7", he remains silent for a long time, while apparently counting on his fingers, then claims he does not know. As for " 2 plus 2", he is able to answer correctly, with no difficulty.

When asked his personal opinion about sexual violence against minors, he is assertive, resourceful, and precise in his replay, "That's absurd!!! It can't happen!" This pattern in his reply is quite different from other moments in the interview and demonstrates his ability to make complex judgements appropriately, to understand complex daily and social elements that define standards of good social conviviality, and to acknowledge the benefit of complying with such standards. It also demonstrates that he understands and assesses reality and its natural and human phenomena correctly.

\section{DISCUSSION}

The rate of feigned amnesia is $20 \%{ }^{11}$, equivalent to the mean simulation rate found in the forensic psychiatric setting (10-20\%). However, according to studies, the true amount of feigned amnesia must be even greater, since it is still underdiagnosed, due either to the feigner's above-average $\mathrm{IQ}^{11}$ or to the lack of application of specific standardized tests to complement the diagnosis. In the case discussed here, no diagnostic tests were applied, but a detailed history and psychiatric examination were performed, which identified an inconsistency in the individual's claim that he had forgotten the facts pursuant to the complaint.

The claim of amnesia of a criminal offense is common in the forensic psychiatric setting. However, organic causes should be investigated in detail. Psychogenic amnesia, although controversial in the forensic community, should be considered, since there are situations in which there is no criminal circumstance or secondary gain with the claim, while such amnesia occurs $^{12}$. In the case in point, there are no sufficient elements to consider a hypothesis of psychogenic amnesia.

Ideally, psychometric tests should be applied to assess memory and simulation, minimizing diagnostic divergences and the resulting juridical repercussions. When an individual feigns amnesia and his intentional production of this symptom goes undetected, the result may be to avert or eliminate criminal sanctions against him, even though his capacity to understand and determine his acts is preserved. On the other hand, the assumption of simulation occurs, as in the case in point, when the only purported symptom is the claim of amnesia in relation to the alleged criminal offense.

It is common to refer to amnesia of criminal acts in cases of extreme violence ${ }^{13}$ or individuals who have consumed alcohol ${ }^{3,14,15}$. This is justified because alcohol intoxication causes alterations in the hippocampus that impair encoding memory and lead to a "blackout". Under Brazilian legislation, situations of intentional alcohol intoxication (except for addiction, fortuitous cases, or force majeure), are considered imputable based on the legal principal of actio libera in causa. In the case analyzed here, the accused denied any abusive use of alcohol products.

Simulated amnesia should always be considered in the presence of psychopathological alterations that are not consistent with classically known syndromes. There are few Brazilian studies on alleged amnesia in sexual crimes.

In this case, the claim of amnesia related to the fact in question and the reports of episodes of psychomotor agitation contrast starkly with the preserved state of other psychological outputs and his resourcefulness in answering points in the interview that denoted his interest in clarifying the facts. He also provided approximate answers when reporting his date of birth (apparently erring his year of birth intentionally) or pointing to the difference between a bird and an airplane (answering reversely with a similarity, "they both fly"), alternating with evasive answers when elements relating to the alleged crime were addressed, alongside the lack of a reply concerning his psychiatric treatment.

As for the criminal dynamics of the offense, the examinee had offered to give the victim a cellphone in order for the latter to engage in the libidinous act. After the offense, in his deposition, he simply said that he could not remember the victim because he suffers from a mental illness. However, his acts were planned and he had full knowledge of their consequences. 
An evaluation of the victim would be relevant for analyzing the discrepancies between the victim's and the offender's reports of the act. However, at the Forensic Psychiatric Examiner's Office in which the examination was performed, there was no evaluation of the victim because the court had only ordered an examination of the accused.

The claim of "forgetting" was inconsistent with observations in the forensic examination. The individual was able to answer several questions related to both recent and remote facts and information, with no amnesia or hypomnesia. His claimed lack of recollection occurred specifically in relation to the facts alleged in the criminal complaint. There appears to have been clear intent to evade responsibility for his actions. Thus, the final forensic conclusion was that the claim of amnesia in relation to this criminal offense was the result of simulation.

\section{CONCLUSION}

A detailed assessment of psychopathological signs and symptoms is essential for impartially establishing, identifying, and distinguishing between a patient with a true organic or mental problem and one who is feigning an illness or symptom in order to obtain compensation or secondary gain.

\section{INDIVIDUAL CONTRIBUTIONS}

Cláudia Cristina Studart Leal - Was responsible for planning, drafting, preparing the article and forecasting the final content.

Alexandre Martins Valença - Was responsible for the design of the article, critical review and final approval of the text.

\section{CONFLICTS OF INTEREST}

Cláudia Cristina Studart Leal and Alexandre Martins Valença have no conflicts of interest to declare.

\section{REFERENCES}

1. Wortzel HS, Arciniegas DB. Amnesia and crime: A neuropsychiatric response. J Am Acad Psychiatry Law. 2008;36:218-23.

2. Grondal P, Vaeroy H, Dahl AA. A study of amnesia in homicide cases and forensic psychiatric experts' examination of such claims. Int J Law Psychiatry. 2009;32:281-7.

3. Cima M, Nijman H, Merkelbach H, Kremer K, Hollnack S. Claims of crime-related amnesia in forensic patients. Int J Law Psychiatry. 2004;27:215-21.

4. Pyszora NM, Barker AF, Kopelman MD. Amnesia for criminal offences: A study of life sentence prisoners. J Forensic Psychiatr Psychol. 2003;14:475-90.

5. Taylor PJ, Kopelman MD. Amnesia for Criminal Offenses. Psychol Med. 1984;14:581-8.

6. Bourget D, Bradford JMW. Sex Offenders who claim Amnesia for their Alleged Offense. Bull Am Acad Psychiatry Law. 1995;23:299-307.

7. Jelicic M. Testing Claims of Crime-Related Amnesia. Front Psychiatry. 2018;9:617.

8. Valença AM, Meyer LF, Freire R, Mendlowicz MV, Nardi AE. A forensic-psychiatric study of sexual offenders in Rio de Janeiro. Braz J Forensic Leg Med. 2015;31:23-8.

9. Valença AM, Nascimento I, Nardi AE. Relação entre crimes sexuais e transtornos mentais e do desenvolvimento: uma revisão. Rev Psiq Clin. 2013;40(3):97-104.

10. Law no. 12,015, of August 7, 2009. Available from: http://www.planalto.gov.br/ ccivil_03/_Ato2007-2010/2009/Lei/L12015.htm\#art3. Accessed in: May 30, 2019,

11. Bourget D, Whitehurst L. Amnesia and crime. J Am Acad Psychiatry Law. 2007;35:469-80.

12. Giger P, Merten T, MerckelbackH. Tatbezogene Amnesien - authentisch oder vorgetäuscht? Fortschr Neurol Psychiatr. 2012;80:368-81.

13. Woodworth M, Porter S, Brinke L, Doucette NL, Peace K, Campbell MA. A comparison of memory for homicide, non-homicidal violence, and positive life experiences. Int I Law Psychiatry. 2009;32:329-34

14. Stout RG, Farooque RS. Claims of amnesia for criminal offenses: Psychopathology, substance abuse, and malingering. J Forensic Sci. 2008;53:1218-21.

15. Menzies RPD. Homicide in the Canadian Prairies: Spousal killers, amnesia and self-harm. Med Sci Law. 2005:45:288-96. 